\title{
PENINGKATAN KEMAMPUAN PEMAHAMAN KONSEP MELALUI METODE PENEMUAN TERBIMBING BERBANTUAN SOFTWARE AUTOGRAPH PADA MATA KULIAH KALKULUS PEUBAH BANYAK DI FKIP UMSU
}

\author{
Ismail Hanif Batubara \\ Program Studi Pendidikan Matematika Universitas Muhammadiyah Sumatera Utara \\ ismailhanif@umsu.ac.id
}

\begin{abstract}
The purpose of this study was to find out: (1) Is the improvement in students' understanding of mathematical concepts given guided discovery method assisted by software Autograph higher than students who were given guided discovery method learning without Autograph software, (2) Is there an interaction between learning with students' initial mathematical ability to increase the ability to understand student mathematical concepts. This research is a quasi-experimental study. The population of this study is that all classes in the fourth semester mathematics education study program are approximately 184 people. Randomly, two classes were selected from six classes. The experimental class was treated with a guided discovery method assisted by autograph and control class given a guided discovery method without the help of autograph. The instrument used is a description test. Data analysis was performed by analysis of two-way variance (ANAVA). The results showed (1) Increased ability to understand mathematical concepts of groups of students who obtained guided discovery method learning using Autograph software higher than the group of students who received learning through guided discovery methods without software autograph. (2) There is no interaction between the learning model and the initial ability of students to increase the ability to understand students' mathematical concepts.
\end{abstract}

Keywords: ability of concept understanding, Guided Discovery Method, Autograph Software.

\begin{abstract}
Abstrak. Tujuan dari penelitian ini adalah untuk mengetahui: (1) Apakah peningkatan kemampuan pemahaman konsep matematik mahasiswa yang diberi pembelajaran metode penemuan terbimbing berbantuan software Autograph lebih tinggi dari pada mahasiswa yang diberi pembelajaran metode penemuan terbimbing tanpa software Autograph, (2) Apakah terdapat interaksi antara pembelajaran dengan kemampuan awal matematik mahasiswa terhadap peningkatan kemampuan pemahaman konsep matematik mahasiswa. Penelitian ini merupakan penelitian quasi eksperimen. Populasi dari penelitian ini adalah seluruh kelas prodi pendidikan matematika semester empat yang berjumlah kurang lebih 184 orang. Secara acak, dipilih dua kelas dari enam kelas. Kelas eksperimen diberi perlakuan metode penemuan terbimbing berbantuan autograph dan kelas control diberi perlakuan metode penemuan terbimbing tanpa bantuan autograph. Instrumen yang digunakan adalah tes uraian. Analisis data dilakukan dengan analisis varians (ANAVA) dua jalur. Hasil penelitian menunjukkan (1) Peningkatan kemampuan pemahaman konsep matematis kelompok mahasiswa yang memperoleh pembelajaran metode penemuan terbimbing dengan menggunakan software Autograph lebih tinggi dibandingkan dengan kelompok mahasiswa yang memperoleh pembelajaran melalui metode penemuan terbimbing tanpa software autograph. (2) Tidak terdapat interaksi antara model pembelajaran dengan kemampuan awal mahasiswa terhadap peningkatan kemampuan pemahaman konsep matematik mahasiswa
\end{abstract}

Kata Kunci: Kemampuan Pemahaman Konsep, Metode Penemuan Terbimbing, Software Autograph

\section{PENDAHULUAN}

Penguasaan materi matematika menjadi suatu keharusan yang tidak bisa ditawar lagi dalam penataan nalar dan pengambilan keputusan serta hasil belajar. Menurut Dachi (2017) menyatakan bahwa ada lima macam hasil belajar dari peserta didik yaitu bentk tertulis, penugasan, hasil karya, dan pengumpulan hasil kerja mahasiswa. Penggunaan beberapa media seperti software, powerpoint dan sebagainya akan memantapkan hasil belajar peserta 
didik. Menurut Wahyuni (2017) menyatakan bahwa hasil belajar mahasiswa lebih baik menggunakan multimedia power point daripada menggunakan metode konvensional, karena dapat membuat mahasiswa tersebut memiliki ketuntasan dalam proses belajar yang maksimal. Sesuai dengan profil lulusan program studi pendidikan matematika UMSU, dinyatakan bahwa lulusan sarjana pendidikan matematika harus mampu menjadi pendidik dan mendidik serta melakukan pembelajaran matematika tingkat pendidikan dasar dan menengah. Tapi sayangnya masih banyak mahasiswa yang tidak menguasai materi-materi yang ada pada mata kuliah kapita selekta pendidikan yang merupakan materi pendidikan di sekolah.

Sebagai contoh banyak mahasiswa yang tidak mampu dalam menggambarkan sebuah grafik dari fungsi yang diberikan. Belum lagi materi- materi lain seperti integral, barisan dan deret dan lain sebagainya, masih banyak mahasiswa yang masih ragu dan bimbang dalam menyelesaikan dan menentukan solusi-solusi dari permasalahan-permasalahan yang muncul. Padahal untuk menjadi seorang guru, materi-materi seperti di atas haruslah bisa dikuasai oleh seseorang yang menyandang profesi sebagai guru. Kurangnya pemahaman konsep mahasiswa terhadap materi tersebut menjadi sebuah dilema tersendiri bagi mahasiswa. Santrock (Irawati, 2014:208) menyatakan bahwa pemahaman konsep adalah aspek kunci dari pembelajaran, salah satu tujuan pengajaran yang penting adalah membantu siswa memahami konsep utama dalam suatu subjek bukan hanya mengingat fakta-fakta yang terpisah-pisah. Ketidaksesuaian antara fakta dengan yang diharapkan saat ini menjadi latarbelakang penulis dalam menuliskan laporan penelitian ini.

Penerapan pembelajaran penemuan terbimbing merupakan salah satu dari solusi permasalahan di atas. Shadiq (2009:12) menjelaskan bahwa pembelajaran penemuan terbimbing merupakan suatu pembelajaran dimana siswa diberikan suatu situasi atau masalah, yang selanjutnya melakukan pengumpulan data, membuat dugaan (konjektur), mencoba-coba (trial and error), mencari dan menemukan keteraturan (pola), menggeneralisasi atau menyusun rumus beserta bentuk umum, membuktikan benar tidaknya dugaannya itu. Oleh karena itu pembelajaran dengan penemuan terbimbing memungkinkan siswa untuk membangun sendiri pengetahuannya melalui kegiatankegiatan yang dirancang, sehingga membuat suatu kesimpulan berdasarkan pemahaman siswa.

Bantuan ICT seperti software Autograph juga dapat menarik minat mahasiswa terhadap pembelajaran matematika. Karnasih (2008) juga mengatakan bahwa "Autograph leads the way in the use of dependent, selectable mathematics objescts to help student get to grips with the principles of probability and statistics, graph, coordinat geometry, in both 2D and 3D".

Pendapat ahli tersebut menjelaskan bahwa autograph dapat membantu siswa untuk memahami materi-materi pembelajaran seperti probabilitas, statistik, dan geometri karena autograph memiliki lembar kerja 2D dan 3D. Dengan demikian dapat disimpulkan bahwa penggunaan software Autograph dapat membantu para pendidik dan anak didik dalam proses belajar dan pembelajaran di sekolah. Berdasarkan permasalahan di atas, serta beberapa solusi yang disebutkan sebelumnya peneliti mencoba untuk menggabungkan pembelajaran penemuan terbimbing dengan media teknologi komputer (Autograph), untuk meningkatkan kemampuan pemahaman konsep matematis mahasiswa.

Tujuan artikel ini adalah untuk mengetahui: (1) Apakah peningkatan kemampuan pemahaman konsep matematik mahasiswa yang diberi pembelajaran metode penemuan terbimbing berbantuan software Autograph lebih tinggi dari pada mahasiswa yang diberi pembelajaran metode penemuan terbimbing tanpa software Autograph, (2) Apakah terdapat interaksi antara pembelajaran dengan kemampuan awal matematik mahasiswa terhadap peningkatan kemampuan pemahaman konsep matematik mahasiswa. 


\section{METODE}

Populasi dari penelitian ini adalah seluruh kelas prodi pendidikan matematika semester empat yang berjumlah kurang lebih 184 orang. Sedangkan yang menjadi sampel pada penelitian ini adalah dua kelas yang dipilih dari kelas yang sudah ada pada prodi pendidikan matematika semester empat Fakultas Keguruan dan Ilmu Pendidikan Universitas Muhammadiyah Sumatera Utara tahun ajaran 2017/2018.

Penelitian ini merupakan penelitian quasi eksperiment. Penelitian ini dilakukan dengan metode penemuan terbimbing berbantuan autograph. Secara garis besar disimpulkan bahwa penelitian ini dilaksanakan dengan tahapan: (1) Tahap penyusunan perangkat pembelajaran dan instrument penelitian yang meliputi tes awal dan sebagainya (2) Tahap pelaksanaan eksperimen berupa pemberian perlakuan pembelajaran, dan (3) Tahap analisis hasil penelitian. Setiap tahapan didesain sedemikian sehingga diperoleh data yang valid sesuai dengan karakteristik variabel dan tujuan penelitian. Data yang akan dikumpulkan dalam penelitian ini adalah data yang berkaitan dengan hasil belajar mahasiswa yang diambil menggunakan test. Tes dilakukan dengan memberikan soal-soal uraian (essay). Tes yang diberikan berupa soal pretest dan soal posttest.

Pengolahan data diawali dengan menguji persyaratan statistik yang diperlukan sebagai dasar dalam pengujian hipotesis, antara lain adalah uji normalitas data dan uji homogenitas varians. Selanjutnya, dilakukan uji- t, regresi dan korelasi yang disesuaikan dengan permasalahannya. Seluruh perhitungan statistik pada penelitian ini menggunakan bantuan program komputer SPSS 16.

Hipotesis 1: Untuk menguji peningkatan kemampuan pemahaman konsep matematis siswa.

$\mathrm{H}_{0}: \mu_{x}=\mu_{y}$

$\mathrm{H}_{\mathrm{a}}: \mu_{x} \neq \mu_{y}$

Keterangan:

$\mu_{x}$ : Peningkatan kemampuan pemahaman konsep matematik mahasiswa yang diajarkan dengan metode penemuan terbimbing berbantuan autograph.

$\mu_{y}$ : Peningkatan kemampuan pemahaman konsep matematik yang diajarkan dengan metode penemuan terbimbing tanpa autograph.

Untuk menguji hipotesis ini digunakan rumus uji t dengan bantuan SPSS 16 dengan kriteria pengujiannnya adalah tolak $\mathrm{H}_{0}$ jika $t_{\text {tabel }}<t_{\text {hitung }}$ dan terima $\mathrm{H}_{0}$ untuk kondisi lainnya dengan taraf signifikansi yang telah ditentukan.

Hipotesis 2: Untuk menguji interaksi antara pembelajaran dan kemampuan awal matematik mahasiswa terhadap peningkatan kemampuan pemahaman konsep mahasiswa.

$\mathrm{H}_{0}: \quad \mu_{11}-\mu_{12}=\mu_{21}-\mu_{22}=\mu_{31}-\mu_{32}$

$\mathrm{H}_{\mathrm{a}}$ : Sedikitnya ada satu selisih rata-rata kemampuan pemahaman konsep matematik mahasiswa yang berbeda dari yang lainnya

Keterangan:

$\mu_{11}$ : Kelompok tinggi kemampuan awal matematik mahasiswa yang diajarkan dengan metode penemuan terbimbing berbantuan autograph untuk peningkatan kemampuan pemahaman konsep matematik mahasiswa

$\mu_{12}$ : Kelompok tinggi kemampuan awal matematik mahasiswa yang diajarkan dengan metode penemuan terbimbing tanpa autograph untuk peningkatan kemampuan pemahaman konsep matematik mahasiswa. 
Untuk menguji hipotesis 2 digunakan uji statistik anava dua jalur dengan menggunakan program SPSS 16.0. Kriteria pengujiannya adalah terima $\mathrm{H}_{0}$ jika nilai signifikansi (sig) lebih besar dari 0,05 dalam hal lainnya jika nilai signifikansi (sig) lebih kecil dari $0,05 \mathrm{H}_{0}$ ditolak.

\section{HASIL DAN PEMBAHASAN}

Deskripsi Hasil $N$-gain Kemampuan Pemahaman konsep Matematika di Kelas Eksperimen I dan Kelas eksperimen II

Tabel 1. Hasil $N$-gain Kemampuan Pemahaman konsep Matematika Pada Kedua Kelas Sampel

\begin{tabular}{ccccc}
\hline Kelas & $\boldsymbol{X}_{\text {maks }}$ & $\boldsymbol{X}_{\min }$ & $\boldsymbol{X}_{\text {rata-rata }}$ & SD \\
\hline Eksperimen I & 1.00 & 0.25 & 0.66 & 0.68 \\
\hline Eksperimen II & 1.00 & 0.20 & 0.50 & 0.22 \\
\hline
\end{tabular}

Agar lebih jelas perbedaannya maka digambarkan dalam diagram batang pada gambar 1 berikut ini.

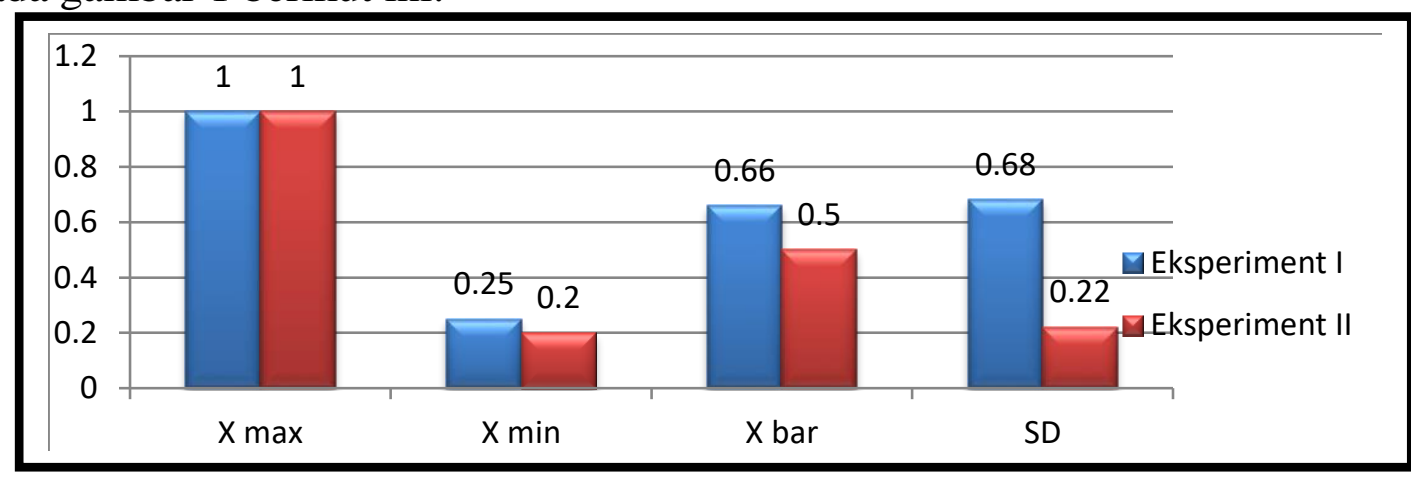

Gambar 1. Diagram Batang $N$-gain Kemampuan Pemahaman konsep

Pada Tabel 1 dan gambar 1 di atas terlihat bahwa nilai tertinggi $\mathrm{N}$-gain pada kedua kelas ekperimen sebesar 1. Sedangkan untuk nilai rata-rata $N$-gain kelas eksperimen I sebesar 0,66 dan kelas eksperimen II sebesar 0,50. Jadi rata-rata $N$-gain kelas eksperimen I lebih tinggi sedikit dibandingkan rata-rata $\mathrm{N}$-gain dikelas eksperiment II. Dari perolehan ini maka selisih rata-rata $\mathrm{N}$-gain antara kelas ekperimen I dan kelas eksperiment II sangat tipis yakni sebesar 0,16 .

\section{Uji Normalitas pada $N$-gain Kedua Kelas}

Hipotesis yang diuji untuk mengetahui normalitas kelompok data $\mathrm{N}$-gain kemampuan pemahaman konsep matematik adalah:

$\mathrm{H}_{0} \quad: \mathrm{f}(\mathrm{x})=$ normal

$\mathrm{H}_{\mathrm{a}} \quad: \mathrm{f}(\mathrm{x}) \neq$ normal

Tabel 2. Hasil Uji Normalitas $N$-gain Kedua Kelas

One-Sample Kolmogorov-Smirnov Test

\begin{tabular}{|ll|r|r|}
\hline & & \multicolumn{1}{c|}{ eks1 } & \multicolumn{1}{c|}{ eks2 } \\
\hline N & & 30 & 30 \\
Normal Parameters & Mean & .7933 & .6623 \\
& Mtd. Deviation & .13760 & .14776 \\
Most Extreme Differences & Absolute & .090 & .166 \\
& Positive & .090 & .166 \\
& Negative & -.090 & -.105 \\
Kolmogorov-Smirnov Z & & .494 & .910 \\
Asymp. Sig. (2-tailed) & & .967 & .380 \\
\hline a. Test distribution is Normal. & & \\
\hline
\end{tabular}


Dari hasil uji Kolmogorov-Smirnov test tersebut, diketahui bahwa nilai Signifikansi kelas eksperimen I sebesar 0.494 sedangkan kelas eksperimen II sebesar 0.910. Karena nilai signifikansi kelas eksperimen $\mathrm{I}(=0.494)$ maka sig eks $\mathrm{I}>\alpha(0,2000>0,05)$ sehingga data $N$-gain kelas eksperimen I berdistribusi normal, dan untuk kelas eksperimen II nilai sig $>\alpha(0.910>0,05)$, artinya data $N$-gain kelas eksperimen II juga berdistribusi normal. Jadi data $N$-gain kelas eksperimen I dan kelas eksperimen II berasal dari data berdistribusi normal. Dengan demikian data $N$-gain kemampuan pemahaman konsep secara keseluruhan dapat disimpulkan berdistribusi Normal.

\section{Uji Homogenitas pada $N$-gain Hasil Belajar}

Setalah melalui tahap uji normalitas, data $N$-gain juga harus melalui tahap uji Homogenitas. Pada penelitian ini uji homogenitas menggunakan uji F. Hipotesis yang diuji untuk mengetahui homogenitas kelompok data $N$-gain hasil belajar adalah:

$\mathrm{H}_{0}: \sigma_{1}^{2}=\sigma_{2}^{2}$

$\mathrm{H}_{\mathrm{a}}: \sigma_{1}^{2} \neq \sigma_{2}^{2}$

Keterangan:

$\sigma_{1}^{2}$ adalah varians skor kelompok model pembelajaran berbasis masalah

$\sigma_{2}^{2}$ adalah varians skor kelompok kelas control.

Tabel 3. Hasil Uji Homogenitas $N$-gain Kedua Kelas

Test of Homogeneity of Variances

kemampuan pemahaman konsep

\begin{tabular}{|c|c|c|c|}
\hline Levene Statistic & $\mathrm{df1}$ & $\mathrm{df2}$ & Sig. \\
\hline .041 & 1 & 78 & .841 \\
\hline
\end{tabular}

Dari hasil levene menggunakan program SPSS 22 tersebut, diketahui bahwa untuk pengujian homogenitas dengan uji Levene nilai sig $>\alpha(0.841>0,05)$ dan $F_{\text {hitung }}$ sehingga hipotesis nol diterima yang berarti semua populasi mempunyai varians yang sama/homogen. Dengan demikian data $\mathrm{N}$-gain kemampuan pemahaman konsep secara keseluruhan dapat disimpulkan memliki varians yang sama atau homogen. Berdasarkan pengujian Normalitas dan homogenitas di atas disimpulkan bahwa data $N$-gain kemampuan pemahaman konsep berdistribusi normal dan memiliki varians yang sama.

\section{Uji Hipotesis Pertama}

Dari hasil uji prasyarat analisis yakni uji normalitas dan homogenitas menunjukkan bahwa data $\mathrm{N}$-gain kemampuan pemahaman konsep siswa berdistribusi normal dan varians dari setiap kelompok data sama, maka untuk menganalisisnya menggunakan uji statistik parametrik yakni menggunakan uji $\mathrm{t}$ dengan hipotesis statistik yang harus diuji untuk kemampuan pemahaman konsep dirumuskan sebagai berikut:

$\mathrm{H}_{0}: \mu_{x}=\mu_{y}$

$\mathrm{H}_{\mathrm{a}}: \mu_{x} \neq \mu_{y}$

Keterangan:

$\mu_{x}$ : Peningkatan kemampuan pemahaman konsep matematis siswa yang diajarkan dengan metode penemuan terbimbing berbantuan autograph.

$\mu_{y}$ : Peningkatan kemampuan pemahaman konsep matematis siswa yang diajarkan dengan metode penemuan terbimbing tanpa autograph 
Tabel 4. Hasil Uji t Kemampuan Pemahaman Konsep Matematik Independent Samples Test

\begin{tabular}{|c|c|c|c|c|c|c|c|c|c|c|}
\hline & \multicolumn{2}{|c|}{$\begin{array}{l}\text { Levene's Test for } \\
\text { Equality of } \\
\text { Variances }\end{array}$} & \multicolumn{7}{|c|}{ t-test for Equality of Means } \\
\hline & & \multirow[b]{2}{*}{$\mathrm{F}$} & \multirow[b]{2}{*}{ Sig. } & \multirow[b]{2}{*}{$\mathrm{t}$} & \multirow[b]{2}{*}{$\mathrm{df}$} & \multirow{2}{*}{$\begin{array}{l}\text { Sig. (2- } \\
\text { tailed) }\end{array}$} & \multirow{2}{*}{$\begin{array}{c}\text { Mean } \\
\text { Difference }\end{array}$} & \multirow{2}{*}{$\begin{array}{l}\text { Std. Error } \\
\text { Difference }\end{array}$} & \multicolumn{2}{|c|}{$\begin{array}{l}95 \% \text { Confidence } \\
\text { Interval of the } \\
\text { Difference }\end{array}$} \\
\hline & & & & & & & & & Lower & Upper \\
\hline Nilai & $\begin{array}{l}\text { Equal } \\
\text { variances } \\
\text { assumed } \\
\text { Equal } \\
\text { variances not } \\
\text { assumed }\end{array}$ & 6.091 & .016 & 2.507 & 74.219 & .014 & .13825 & .05516 & .02844 & .24806 \\
\hline
\end{tabular}

Berdasarkan hasil perhitungan pada tabel 5.17 di atas dengan menggunakan uji t pada taraf signifikansi $\alpha=0,05$ diperoleh thitung sebesar 2,507 dengan nilai signifikansi 0,16 sedangkan $t_{\text {tabel }}$ sebesar 1,99 . Karena $t_{\text {hitung }}(2,507)>t_{\text {tabel }}(1,99)$ dan nilai signifikansi $(0,014)<\alpha(0,05)$, sehingga $\mathrm{H}_{0}$ ditolak. Maka dapat disimpulkan bahwa peningkatan Kemampuan Pemahaman Konsep matematik mahasiswa yang diajarkan melalui metode pembelajaran penemuan terbimbing berbantuan autograph lebih tinggi dari pada yang diajarkan melalui metode pembelajaran penemuan terbimbing tanpa autograph.

\section{Uji Hipotesis Kedua}

Hipotesis yang diajukan untuk di uji dengan uji ANAVA dirumuskan sebagai berikut:

$\mathrm{H}_{0}: \mu_{11}-\mu_{12}=\mu_{21}-\mu_{22}=\mu_{31}-\mu_{32}$

$\mathrm{H}_{\mathrm{a}}$ : Sedikitnya ada satu selisih rata-rata kemampuan pemahaman konsep matematis siswa yang berbeda dari yang lainnya

Keterangan:

$\mu_{11}$ : Kelompok rendah kemampuan awal matematika siswa yang diajarkan dengan metode pembelajaran penemuan terbimbing berbantuan autograph untuk peningkatan kemampuan pemahaman konsep matematis mahasiswa

$\mu_{12}$ : Kelompok rendah kemampuan awal matematika siswa yang diajarkan dengan metode pembelajaran penemuan terbimbing tanpa autograph untuk peningkatan kemampuan pemahaman konsep matematis mahasiswa

Kriteria pengujiannya adalah jika nilai significance (sig) lebih besar dari $\alpha=0,05$, maka $\mathrm{H}_{0}$ diterima, dalam hal lainnya di tolak.

Tabel 5. Hasil Uji Anava Berdasarkan Pembelajaran dan Kategori KAM

Tests of Between-Subjects Effects

Dependent Variable: Nilai Gain

\begin{tabular}{|l|r|r|r|r|r|}
\hline Source & $\begin{array}{r}\text { Type III Sum of } \\
\text { Squares }\end{array}$ & df & Mean Square & \multicolumn{1}{c|}{ F } & \multicolumn{1}{c|}{ Sig. } \\
\hline Corrected Model & .068 & 5 & .014 & .273 & .927 \\
Intercept & 17.943 & 1 & 17.943 & 358.786 & .000 \\
Kelompok & .025 & 1 & .025 & .491 & .486 \\
KAM & .018 & 2 & .009 & .176 & .839 \\
Kelompok * KAM & .008 & 2 & .004 & .078 & .925 \\
Error & 3.701 & 74 & .050 & & \\
Total & 25.028 & 80 & & & \\
Corrected Total & 3.769 & 79 & & & \\
\hline
\end{tabular}

a. R Squared $=.018$ (Adjusted R Squared $=-.048$ )

Dari tabel 5 di atas terlihat bahwa untuk faktor pembelajaran dan KAM, diperoleh nilai signifikansi sebesar 0,925 . Karena nilai signifikansi lebih besar dari nilai taraf signikan 0,05, maka Ho diterima, yang berarti tidak terdapat interaksi antara pendekatan pembelajaran dengan kemampuan awal siswa terhadap peningkatan kemampuan 
pemahaman konsep matamatik siswa. Jadi, peningkatan kemampuan pemahaman konsep matematik siswa disebabkan oleh perbedaan pembelajaran yang digunakan bukan karena kemampuan awal matematika siswa. Dengan kata lain, tidak terdapat pengaruh secara bersama yang diberikan oleh pembelajaran dan KAM.

Melihat hasil penelitian yang telah dikemukakan di atas, menunjukkan bahwa metode penemuan terbimbing berbantuan Autograph secara signifikan lebih baik dalam meningkatkan hasil belajar siswa dibandingkan dengan metode penemuan terbimbing tanpa bantuan Autograph . Dalam kegiatan pembelajaran ini mahasiswa berkesempatan berinteraksi dengan komunitasnya. Mahasiswa akan saling berbagi ide untuk mengajukan penyelesaian baik di dalam kelompok maupun menyajikan hasil akhirnya di depan kelas. Sehingga mahasiswa dengan mudah dapat menemukan kesalahan-kesalahan pada penyelesaian masalah yang dibuat. Sedangkan bagi mahasiswa berkemampuan tinggi mempunyai kesempatan untuk berlatih menyampaikan ide dan gagasan kepada orang lain dan menghargai pendapat orang lain sehingga sangat memungkinkan dapat menambah pengetahuan mereka.

Namun pada kelas eksperimen kedua yang terjadi tidaklah seperti yang diharapkan. Sebagian besar mahasiswa tidak berupaya maksimum menggunakan segenap kemampuan kognisinya, dan tidak berinteraksi dengan komunitasnya dan mementingkan ego masingmasing. Sehingga mahasiswa bekerja secara individual pada saat menyelesaikan soal. Disamping mahasiswa mementingkan ego masing-masing ,mahasiswa lainnya bergantung pada dosen dalam menyelesaikan soal, sehingga sifat pengulangan meniru dan menghafal sebagai pembentukan pengetahuan dengan dosen sebagai model dan sumber belajar juga terjadi di kelas ini. Dengan demikian, peran aktif mahasiswa serta interaksi yang terjadi sangat minim sekali.

Hal yang membuat tidak terdapat interaksi antara pembelajaran dengan tingkat kemampuan awal matematika mahasiswa terhadap peningkatan hasil belajar mahasiswa adalah faktor pemberian pembelajaran yang relatif sama antar kedua kelas sehingga kemampuan awal matematik siswa tidak memberi pengaruh secara bersamaan terhadap peningkatan hasil belajar mahasiswa.

Berdasarkan temuan di atas dapat disimpulkan bahwa penggunaan metode penemuan terbimbing berbantuan autograph lebih baik dibandingkan dengan metode penemuan terbimbing tanpa bantuan autograph. Hasil temuan ini sejalan dengan penelitian yang dilakukan oleh Afriati (2011), yang menyatakan bahwa siswa yang mendapat penemuan terbimbing berbantuan software Autograph lebih menunjukkan kektifan belajar dari siswa yang mendapat pendekatan biasa. Batubara (2017:103) menyatakan bahwa Peningkatan kemampuan berpikir kritis matematik siswa yang diajarkan melalui pembelajaran berbasis masalah berbantuan autograph lebih tinggi dari pada yang diajarkan melalui pembelajaran berbasis masalah berbantuan geogebra.

\section{SIMPULAN}

Berdasarkan hasil analsis data di atas diperoleh beberapa kesimpulan yang merupakan jawaban atas petanyaan-pertanyaan pada rumusan masalah, diataranya:

1. Peningkatan kemampuan pemahaman konsep matematis kelompok mahasiswa yang memperoleh pembelajaran metode penemuan terbimbing dengan menggunakan software Autograph lebih tinggi dibandingkan dengan kelompok mahasiswa yang memperoleh pembelajaran melalui metode penemuan terbimbing tanpa software autograph.

2. Tidak terdapat interaksi antara model pembelajaran dengan kemampuan awal mahasiswa terhadap peningkatan kemampuan pemahaman konsep matematik mahasiswa 
3. Untuk meningkatkan hasil belajar mahasiswa, pendidik dapat menggunakan metode penemuan terbimbing dengan software autograph sebagai salah satu alternatif.

4. Pendidik diharapkan perlu menambah wawasan tentang teori-teori pembelajaran yang lain (pembelajaran yang inovatif), dan dapat menerapkannya dalam pembelajaran.

5. Dalam setiap pembelajaran pendidik harus menciptakan suasana belajar yang memberi kesempatan kepada mahasiswa untuk mengungkapkan gagasangagasan matematika dalam bahasa dan cara mereka sendiri, sehingga dalam belajar matematika mahasiswa menjadi berani berargumentasi, lebih percaya diri, dan kreatif.

\section{DAFTAR PUSTAKA}

Afriati, V. 2011. Peningkatan Pemahaman Konsep dan Komunikasi Matematika Siswa dengan Pendekatan Penemuan Terbimbing Berbantuan Software Autograph. Jurnal Paradikma, 5(1\&2).

Batubara, I. H. 2017. Peningkatan Kemampuan Pemahaman Konsep Matematis Melalui Model Pembelajaran Berbasis Masalah Berbantuan Autograph Dan Geogebra Di Sma Freemethodist Medan. MES (Journal of Mathematics Education and Science), 3(1), 47-54.

Dachi, S. W. 2017. Upaya Meningkatkan Hasil Belajar Matematika Melalui Strategi Belajar Small Group Work pada Mahasiswa Jurusan Matematika Fakultas Keguruan dan Ilmu Pendidikan Universitas Muhammadiyah Sumatera Utara. Edutech: Jurnal Ilmu Pendidikan dan Ilmu Sosial, 3(1), 109-116.

Karnasih, I. 2008. Paper Presentated in International Workshop: ICT for Teaching and Learning Mathematics. Medan: UNIMED

Irawati, H. 2014. Pengaruh Pembelajaran Penemuan Terbimbing terhadap Kemampuan Pemahaman Matematik Siswa. Prosiding Seminar Nasional Pendidikan Matematika Program Pasca Sarjana STKIP Siliwangi Bandung. Volume 1 ISSN 2355-0473

Shadiq, F. 2009. Model-Model Pembelajaran Matematika SMP. Yogyakarta: P4TK Matematika Depdiknas

Wahyuni, S. 2017 "Perbedaan Hasil Belajar Matematika Siswa Menggunakan Strategi Student Led Review Session Dengan Metode Konvensional. Kumpulan Jurnal Dosen Universitas Muhammadiyah Sumatera Utara. Vol (6) 105-111. 